\title{
THE EFFECT OF CONCENTRATE CONTAINING PROBIOTICS ON FERMENTATION CHARACTERISTICS, METHANOGENESIS AND In vitro NUTRIENT DIGESTILITY
}

\author{
B. Santoso ${ }^{1}$, B. Tj. Hariadi ${ }^{1}$ and H. Abubakar ${ }^{2}$ \\ ${ }^{1}$ Department of Animal Nutrition, Faculty of Animal Science, Fishery and Marine Science, \\ The State University of Papua, Manokwari 98314, Papua Barat - Indonesia \\ ${ }^{2}$ Department of Biology, Faculty of Mathematics and Natural Science, The State University of Papua, \\ Manokwari, Manokwari 98314, Papua Bara - Indonesia \\ CorrespondingE-mail: santosob@lycos.com
}

Received June 11, 2014; Accepted November 19, 2014

\begin{abstract}
ABSTRAK
Tujuan penelitian ini adalah untuk mengevaluasi pengaruh penambahan probiotik dalam konsentrat terhadap karakteristik fermentasi, produksi metana dan kecernaan nutrien secara in vitro. Penelitian ini disusun dalam rancangan acak lengkap yang terdiri atas 4 perlakuan yaitu silase rumput $(\mathrm{G})$; silase rumput + konsentrat tanpa probiotik $(\mathrm{G}+\mathrm{A})$; silase rumput + konsentrat mengandung L. plantarum dan S. cerevisiae $(\mathrm{G}+\mathrm{B})$; silase rumput + konsentrat mengandung L. acidophilus dan $S$. cerevisiae $(\mathrm{G}+\mathrm{C})$; silase rumput + konsentrat mengandung $L$. plantarum dan $L$. acidophilus $(\mathrm{G}+\mathrm{D})$. Data dianalisis menurut rancangan acak lengkap dan dilanjutkan uji wilayah berganda Duncan. Hasil penelitian menunjukkan bahwa konsentrat mengandung bakteri asam laktat (BAL) bervariasi $1.5 \times 10^{6}$ dan $3 \times 10^{7}$ $\mathrm{cfu} / \mathrm{g}$, dan $S$. cerevisiae $3 \times 10^{3} \mathrm{cfu} / \mathrm{g}$. Kombinasi $L$. plantarum dan $S$. cerevisiae $(\mathrm{G}+\mathrm{C})$ dan $L$. acidophilus dan $S$. cerevisiae $(\mathrm{G}+\mathrm{D})$ meningkatkan $(\mathrm{P}<0,01)$ konsentrasi asam propionat. Rata-rata produksi metana pada konsentrat mengandung probiotik $(\mathrm{G}+\mathrm{B}, \mathrm{G}+\mathrm{C}, \mathrm{G}+\mathrm{D})$ menurun $(\mathrm{P}<0,01)$ sebesar $6,9 \%$ dibandingkan konsentrat tanpa probiotik $(\mathrm{G}+\mathrm{B})$. Kecernaan bahan kering dan neutral detergent fiber (NDF) meningkat $(\mathrm{P}<0,01)$ berturut-turut sebesar $25,7 \%$ and $6,3 \%$ pada konsentrat mengandung probiotik $(\mathrm{G}+\mathrm{B}, \mathrm{G}+\mathrm{C}, \mathrm{G}+\mathrm{D})$ dibandingkan konsentrat tanpa probiotik $(\mathrm{G}+\mathrm{A})$. Disimpulkan bahwa penambahan probiotik pada konsentrat meningkatkan proporsi asam propionat, kecernaan nutrien dan menurunkan produksi metana (in vitro).
\end{abstract}

Kata kunci: konsentrat, kecernaan, metana, probiotik, ruminansia

\begin{abstract}
The aim of the experiment was to evaluate the effect of probiotic addition in concentrate on fermentation characteristics, methane $\left(\mathrm{CH}_{4}\right)$ production and in vitro nutrient digestibility. Two strains lactic acid bacteria (LAB) i.e. Lactobacillus plantarum and Lactobacillus acidhophilus, and one strain yeast of Saccharomyces cerevisiae was used as probiotic. This experiment was arranged in a completely randomized design consisted of 4 treatments as follows grass silage $(\mathrm{G})$; grass silage + concentrate without probiotic $(\mathrm{G}+\mathrm{A})$; grass silage + concentrate containing L. plantarum and. S. cerevisiae $(\mathrm{G}+\mathrm{B})$; grass silage + concentrate containing L. acidophilus and. S. cerevisiae $(\mathrm{G}+\mathrm{C})$; grass silage + concentrate containing $L$. plantarum and $L$. acidophilus $(\mathrm{G}+\mathrm{D})$. Data were analyzed as completely randomized design and followed by Duncan's multiple range test. The results showed that the concentrate containing LAB varied $1.5 \times 10^{6}$ and $3 \times 10^{7} \mathrm{cfu} / \mathrm{g}$, and $3 \times 10^{3} \mathrm{cfu} / \mathrm{g}$ of $\mathrm{S}$. cerevisiae. Combination between $L$. plantarum and S. cerevisiae $(\mathrm{G}+\mathrm{B})$, and L. acidophilus and S. cerevisiae $(\mathrm{G}+\mathrm{C})$ in concentrate increased $(\mathrm{P}<0.01)$ propionic acid proportion. The average $\mathrm{CH}_{4}$ production in concentrate containing probiotic $(\mathrm{G}+\mathrm{C}, \mathrm{G}+\mathrm{D}$ and $\mathrm{D}+\mathrm{E})$ was lower by $6.9 \%(\mathrm{P}<0.01)$ compared to concentrate without probiotic $(\mathrm{G}+\mathrm{B})$.
\end{abstract}


The in vitro dry matter $(\mathrm{DM})$ and neutral detergent fiber $(\mathrm{NDF})$ digestibility were higher $(\mathrm{P}<0.01)$ by $25.7 \%$ and $6.3 \%$ respectively, in grass silage substrate with concentrate containing probiotic $(\mathrm{G}+\mathrm{C}, \mathrm{G}+\mathrm{D}$ and $\mathrm{G}+\mathrm{E})$ than in grass silage with concentrate without probiotic $(\mathrm{G}+\mathrm{B})$. In conclusion, addition of probiotic in concentrate could increase in vitro propionic acid proportion, DM and NDF digestibility and reduce $\mathrm{CH}_{4}$ production.

Keywords: concentrate, digestibility, methane, probiotics, ruminant

\section{INTRODUCTION}

There is an increasing interest in research activities to evaluate the potential of secondary plant compound as feed additives instead of chemical compounds i.e. ionophores and antibiotics as manipulators of rumen fermentation to decrease $\mathrm{CH}_{4}$ production. The use of growth promoting antibiotics in animal feeds is banned in Europe due to potential risks such as spread of antibiotic resistance genes (Hong et al., 2005) or the contamination of milk or meat with antibiotics residues. Recently, probiotics have been increasingly evaluated to replace in the use of antibiotics.

Probiotic is a live microbial feed supplement that may beneficially affect the host animal upon ingestion by improving its intestinal microbial balance (Fuller, 1989). Seo et al. (2010) stated that microorganisms sush as Lactobacillus, Streptococcus and Enterococcus are commonly used in probiotic for ruminants. Furthermore, Saccharomyces cerevisiae and Aspergilus oryzae are two primary fungal direct-fed microorganism (DFM) that have been supplemented to diet in ruminants. Seo et al. (2010) stated that propionibacteria ferments lactic acid to propionic acid. Since propionic acid is the major precursor for gluconeogenesis, increaments propionic acid production in the rumen increases of hepatic glucose production. In addition, increased propionic acid may reduce hydrogen available for $\mathrm{CH}_{4}$ production in the rumen. Newbold (1995) revealed that addition of $S$. cerevisiae in ruminant could improve animal production through increasing mechanism of bacteria viability. Mwenya et al. (2004) reported that adding of yeast culture containing $21 \%$ of $S$. cerevisiae in sheep reduced $\mathrm{CH}_{4}$ production by $10 \%$ as compared to control sheep. In in vitro study, Lila et al. (2004) concluded that $S$. cerevisiae stimulated mixed ruminal fermentation with decreased lactate, and a small decrease of $\mathrm{CH}_{4}$ and hydrogen. In the previous in vivo study, most of researchers directly fed probiotic to the animal.
However, this method is less efficient when it is applied to a number of animal. Therefore, the objective of the present study was to evaluate the effect of different concentrate containing probiotics on in vitro fermentation characteristics, $\mathrm{CH}_{4}$ production and nutrient digestibility.

\section{MATERIALS AND METHODS}

\section{Concentrate Preparation}

Rice bran, tofu waste and cassava waste were obtained from small-scale food industry located at Manokwari and Prafi Districts, Manokwari regency. Tofu waste and cassava waste were dried in the oven $60{ }^{\circ} \mathrm{C}$ at least $48 \mathrm{~h}$ and ground to pass a $1 \mathrm{~mm}$ sieve in a Wiley mill. Lactobacillus plantarum was isolated from Pennisetum purpureophoides that has been used in the previous study by Santoso et al. (2012). L. plantarum and L. acidophilus were cultured using MRS broth at $30{ }^{\circ} \mathrm{C}$ for $48 \mathrm{~h}$ (Santoso et al. 2013a), meanwhile $S$. cerevisiae was cultured using malt extract broth at $30{ }^{\circ} \mathrm{C}$ for $48 \mathrm{~h}$ (Newbold et al., 1995). The solid meterials of concentrate were manually mixed by hand and then sprayed on top with culture of LAB and yeast (Table 1).

\section{Donor Animal}

Two ruminally fistulated Ongole crossbreed cattle were used as rumen liquor donor. Animals were fed at $6.8 \mathrm{~kg} \mathrm{DM}$ of king grass to meet their maintenance requirement and adapted for 3 weeks before rumen liquor collection. The feed was offered twice daily at 08:00 and 16:00 h. Rumen liquor was collected before the morning feeding and strained through four layers of cheesecloth into a pre-warmed thermos flask.

\section{In vitro Gas Production and $\mathrm{CH}_{4}$ Measurement}

In vitro gas production was determined in line with the method of Menke and Steingass (1988) previously described by Hariadi and Santoso (2010); Santoso et al. (2013). Briefly, oven-dried samples of about $300 \mathrm{mg}$ were 
Table 1. Ingredients of Concentrate and Chemical Composition of Grass Silage and Concentrates (\%)

\begin{tabular}{|c|c|c|c|c|c|}
\hline & \multirow{2}{*}{ G } & \multicolumn{4}{|c|}{ Concentrates } \\
\hline & & A & B & $\mathrm{C}$ & $\mathrm{D}$ \\
\hline \multicolumn{6}{|l|}{ Ingredients } \\
\hline Cassava waste & - & 40 & 36 & 36 & 36 \\
\hline Tofu waste & - & 20 & 20 & 20 & 20 \\
\hline Rice bran & - & 35 & 35 & 35 & 35 \\
\hline Salt & - & 2 & 2 & 2 & 2 \\
\hline Urea & - & 3 & 3 & 3 & 3 \\
\hline L. plantarum & - & - & 2 & - & 2 \\
\hline S. cerevisiae & - & - & 2 & 2 & - \\
\hline L. acidophilus & - & - & - & 2 & 2 \\
\hline \multicolumn{6}{|c|}{ Chemical composition } \\
\hline Dry matter & 16.7 & 82.0 & 81.0 & 83.0 & 84.1 \\
\hline Organic matter & 91.8 & 93.9 & 93.8 & 92.8 & 93.1 \\
\hline Crude protein & 7.1 & 19.4 & 17.9 & 17.5 & 17.0 \\
\hline NDF & 80.3 & 50.8 & 42.7 & 44.1 & 42.1 \\
\hline $\mathrm{ADF}$ & 54.0 & 21.2 & 20.2 & 23.7 & 20.9 \\
\hline Hemicellulose & 26.3 & 29.6 & 22.5 & 20.4 & 21.2 \\
\hline L. plantarum & - & - & $5.4 \times 10^{6}$ & - & $8.1 \times 10^{7}$ \\
\hline L. acidophilus & - & - & - & $1.9 \times 10^{5}$ & \\
\hline S. cerevisiae & - & - & $6.2 \times 10^{6}$ & $7.4 \times 10^{6}$ & - \\
\hline
\end{tabular}

G: grass silage; A: concentrate without probiotic; B: concentrate containing L. plantarum and S. cerevisiae; C: concentrate containing $L$. acidophilus and S. cerevisiae; D: concentrate containing $L$. plantarum and $L$. acidophilus

weighed into $100 \mathrm{ml}$ glass syringes (Model Fortune, Häberle Labortechnik, Germany) with pistons lubricated with vaseline. Three parallel syringes that contained rumen liquor-buffer mixtures without substrate served as blanks. Buffer solution contained carbonate buffer, macromineral solution, and micromineral solution. The syringes were pre-warmed at $39{ }^{\circ} \mathrm{C}$ overnight, before the addition of $30 \pm 1.0 \mathrm{ml}$ of rumen liquor-buffer mixtures into each syringe. The syringes were incubated in a water bath at 39 ${ }^{\circ} \mathrm{C}$ for $48 \mathrm{~h}$ and were gently shaken every $8 \mathrm{~h}$. The volume of gas released from each syringe was recorded before incubation $(0 \mathrm{~h})$ and $1,2,4,6,8$, $12,24,36$ and $48 \mathrm{~h}$ of incubation.

To facilitate $\mathrm{CH}_{4}$ measurement, glass syringes fitted with an extra outlet containing gas- tight septum for gas sampling as previously demonstrated by Hariadi and Santoso (2010); Santoso et al. (2013). One hundred micro litter of gas was sampled from the headspace of syringe in an airtight syringe at 24 and $48 \mathrm{~h}$ of incubation. Methane was determined by injection $100 \mathrm{ml}$ of gas into a chromatograph gas (GC model 263-50, Hitachi Ltd., Ibaraki, Japan).

At the end of the incubation period, about 10 $\mathrm{ml}$ of syringe contents were sampled. The $\mathrm{pH}$ of medium was recorded immediately using a digital pH meter (Hanna, Hi 8520, Ronchi di Villafranca, Italy). Subsequently, $0.2 \mathrm{ml}$ of sub-samples were pipetted into $1.5 \mathrm{ml}$ micro centrifuge tube containing $1 \mathrm{ml}$ of $25 \mathrm{~g} / 100 \mathrm{ml} \quad(\mathrm{w} / \mathrm{v})$ metaphosphoric acid and centrifuged at $9000 \mathrm{~g}$ for $10 \mathrm{~min}$ for volatile fatty acids (VFA) 
determination. A further $2 \mathrm{ml}$ of sub-samples were added to $2 \mathrm{ml}$ of $20 \mathrm{~g} / \mathrm{l}(\mathrm{w} / \mathrm{v}) \mathrm{NaCl}$ and for $\mathrm{NH}_{3}-\mathrm{N}$ analysis.

\section{In vitro Nutrients Digestibility}

Determinations of DM, organic matter (OM) and neutral detergent fiber (NDF) digestibilities were conducted using in vitro procedure of Tilley and Terry (1963). Twenty five milliliter of rumen liquor-buffer mixtures in a $1: 4(\mathrm{v} / \mathrm{v})$ ratio were dispensed in $100 \mathrm{ml}$ glass tubes containing 250 mg of dry sample consisted of grass silage and concentrate (70 : 30, DM). Triplicates of blank (with no feed sample) and standard (Pangola grass) were included in each run. Rumen liquor was collected in the morning before feeding and strained through four layers of cheesecloth into a pre-warmed thermos flask. Buffer solution contained $9.8 \mathrm{~g} \mathrm{NaHCO}_{3}, 9.3 \mathrm{~g} \mathrm{NaHPO}_{4} .12 \mathrm{H}_{2} \mathrm{O}$, $0.47 \mathrm{~g} \mathrm{NaCl}, 0.57 \mathrm{~g} \mathrm{KCl}, 0.04 \mathrm{CaCl}_{2}, 0.12 \mathrm{~g}$ $\mathrm{MgSO}_{4} .7 \mathrm{H}_{2} \mathrm{O}$ per $1000 \mathrm{ml}$ distilled water. After gassing $\mathrm{CO}_{2}$ in the tube, corks were tightly placed over the tubes and were incubated in a water bath at $39{ }^{\circ} \mathrm{C}$ for $48 \mathrm{~h}$. After $48 \mathrm{~h}$ of microbial incubation, the samples were incubated at $39{ }^{\circ} \mathrm{C}$ for $48 \mathrm{~h}$ with acid-pepsin. Therefore, the contents were filtered through pre-weighed Gooch crucibles and dried at $105{ }^{\circ} \mathrm{C}$ for $24 \mathrm{~h}$. The percent loss in weight was determined and presented as in vitro DM digestibility (IVDMD) and in vitro NDF digestibility (IVNDFD). The residue left was ashed at $550{ }^{\circ} \mathrm{C}$ for determination of in vitro OM digestibility (IVOMD).

\section{Chemical Analysis}

Dried samples were used to determine DM, $\mathrm{OM}$ and $\mathrm{CP}$ according to procedure of AOAC (2005). The fiber content i.e. NDF and acid detergent fiber (ADF) were analyzed using Van Soest et al. (1991) method with some modification i.e. NDF was determined without the use of $\mu$-amylase and sodium sulfite.

\section{Statistical Analysis}

Data were analyzed as completely randomized design using GLM procedure of SAS (SAS Institute Inc., Cary, NC). Duncan's multiple range test was used to identify the significant differences between means.

\section{RESULTS AND DISCUSSION}

\section{Chemical Composition of Feeds}

The chemical composition of king grass silage and concentrate used in this study are presented in Table 1. Grass silage used in the present experiment had $7.1 \%$ of $\mathrm{CP}$, which is comparable with the threshold value of $7 \%$. Minson and Milford (1966) revealed that digestibility can declined when animals are fed herbage with a $\mathrm{CP}$ content below $7 \%$, due to microbial activity in the rumen depressed by lack of nitrogen. Dry matter content of king grass silage was lower than the ideal DM content of $20 \%$ as recommended by McDonald et al. (1991). The lower DM content of silage obtained in this study could be due to high rainfall during silage preparation. Dry matter and OM contents in all concentrates used in this experiment were similar, varied from $81.0-84.1 \%$ and $92.8-93.9 \%$, respectively. Addition of $3 \%$ urea in concentrates increased CP content up to $15 \%$. The NDF content in concentrate A was slightly higher than other concentrates may be due to cassava waste was replaced by probiotics isolate in concentrate $\mathrm{B}, \mathrm{C}$ and $\mathrm{D}$. The population of LAB and yeast in the concentrate was lower than concentration probiotic of $5 \times 10^{9} \mathrm{cfu} / \mathrm{g}$ as used by Lila et al. (2004).

\section{Fermentation Characteristics}

The $\mathrm{pH}$ value, concentrations of $\mathrm{NH}_{3}-\mathrm{N}$ and VFA are presented in Table 2. The $\mathrm{pH}$ value in substrate consisted of grass silage and concentrate containing L. acidophilus and S. cerevisiae $(\mathrm{R}+\mathrm{C})$ and concentrate containing $L$. plantarum and $L$. acidophilus $(\mathrm{R}+\mathrm{D})$ were lower $(\mathrm{P}<0.01)$ than control subtrate. The lower $\mathrm{pH}$ value could be due to higher lactic acid concentration that produced by $\mathrm{LAB}$ thus suppressed $\mathrm{pH}$ value. However, the $\mathrm{pH}$ value in all treatments ranged from 6.82 to 6.91 , which is in the optimal range $\mathrm{pH} 6.7 \pm 0.5$ required to maintain normal cellulolysis (Van Soest, 1994) and above 6.0, required for microbial protein synthesis (Russel et al., 1992). In the previous in vitro study, Lila et al. (2004) noted that addition of probiotic contained $5 \times 10^{9}$ of $S$. cerevisiae cells/g had no significant effect on $\mathrm{pH}$ value. A different result has been reported by Mwenya et al. (2004) that supplementation of $4 \mathrm{~g} / \mathrm{d}$ of $S$. cerevisae significantly increased $\mathrm{pH}$ in the sheep rumen.

Ammonia concentration is a balance between degradation of feed protein and uptake of ammonia for synthesis protein of microbial. During fermentation in rumen, feed protein can be degraded by microbe to $\mathrm{NH}_{3} \mathrm{~N}$. Concentration of $\mathrm{NH}_{3} \mathrm{~N}$ in substrate concentrate without 
Table 2. In vitro Fermentation Characteristics in Supernatant after $48 \mathrm{~h}$ of Incubation

\begin{tabular}{lccccccc}
\hline & \multicolumn{5}{c}{ Treatments } & \multirow{2}{*}{ SEM } & P \\
\cline { 2 - 6 } & $\mathrm{G}$ & $\mathrm{G}+\mathrm{A}$ & $\mathrm{G}+\mathrm{B}$ & $\mathrm{G}+\mathrm{C}$ & $\mathrm{G}+\mathrm{D}$ & & \\
\hline $\mathrm{pH}$ & $6.91^{\mathrm{a}}$ & $6.87^{\mathrm{a}}$ & $6.86^{\mathrm{ab}}$ & $6.83^{\mathrm{b}}$ & $6.82^{\mathrm{b}}$ & 0.01 & 0.01 \\
$\mathrm{NH}_{3}-\mathrm{N}(\mathrm{mg} / 100 \mathrm{ml})$ & 34.4 & 38.8 & 37.3 & 37.6 & 38.6 & 3.25 & 0.33 \\
$\mathrm{C} 2(\mathrm{~mol} / 100 \mathrm{~mol})$ & 58.4 & 59.1 & 57.3 & 58.5 & 56.7 & 1.50 & 0.65 \\
$\mathrm{C} 3(\mathrm{~mol} / 100 \mathrm{~mol})$ & $15.5^{\mathrm{b}}$ & $15.5^{\mathrm{b}}$ & $20.4^{\mathrm{a}}$ & $19.7^{\mathrm{a}}$ & $18.3^{\mathrm{ab}}$ & 0.34 & 0.01 \\
$\mathrm{C} 4(\mathrm{~mol} / 100 \mathrm{~mol})$ & 26.1 & 25.4 & 22.3 & 21.8 & 25.0 & 2.39 & 0.76 \\
$\mathrm{C} 2 / \mathrm{C} 3$ & 3.8 & 3.8 & 2.9 & 3.0 & 3.1 & 0.34 & 0.19 \\
Total VFA $(\mathrm{mM})$ & $90.8^{\mathrm{b}}$ & $103.5^{\mathrm{ab}}$ & $112.3^{\mathrm{a}}$ & $113.0^{\mathrm{a}}$ & $112.1^{\mathrm{a}}$ & 2.28 & 0.01 \\
$\mathrm{CH} 4$ (ml) & $7.3^{\mathrm{a}}$ & $6.8^{\mathrm{b}}$ & $6.4^{\mathrm{b}}$ & $6.4^{\mathrm{b}}$ & $6.2^{\mathrm{c}}$ & 0.08 & 0.01 \\
\hline
\end{tabular}

G: grass silage; A: concentrate without probiotic; B: concentrate containing L. plantarum and S. cerevisiae; C: concentrate containing L. acidophilus and S. cerevisiae; D: concentrate containing L. plantarum and $L$. acidophilus

Mean values with different superscript letters within the same row are significantly different $(\mathrm{P}<0.01)$

probiotic $(\mathrm{G}+\mathrm{A})$ was similar to concentrate containing probiotic $(\mathrm{G}+\mathrm{B}, \mathrm{G}+\mathrm{C}$ and $\mathrm{G}+\mathrm{D})$. Result from this study is supported by Lila et al. (2004) and Mwenya et al. (2004) concentration of ammonia $\mathrm{N}$ did not change by addition of probiotic i.e. S. saccharomyces or LAB. A slightly higher $\mathrm{NH}_{3}-\mathrm{N}$ concentration observed in substrate silage combined with concentrate compared to silage alone could due to concentrate used in this study had higher CP concent. Concentration of $\mathrm{NH}_{3} \mathrm{~N}$ in the present study ranged from 34.4 to $38.8 \mathrm{mg} / 100 \mathrm{ml}$, and were above the threshold value for both maximum fiber digestion as recommended by Abdulrazak et al. (1997).

The proportion of propionic acid (C3) and total VFA concentration was higher $(\mathrm{P}<0.05)$ in concentrate with addition of probiotic $(\mathrm{G}+\mathrm{B}, \mathrm{G}$ $+\mathrm{C}$ and $\mathrm{G}+\mathrm{D})$. This result is supported by Lila et al. (2006) that addition of S. cerevisiae increased proportion of propionic acid and total VFA. Meanwhile, Mwenya et al. (2004) stated that proportion propionic acid and concentration total VFA in the rumen were similar between sheep fed LAB or $S$. saccharomyces and control sheep. Increasing proportion of propionic acid could be due to increased lactic acid production by LAB. Furthemore, lactic acid to be converted by lactic acid utilizing bacteria such as Megasphaera elsdenii to propionic acid. Increasing proportion of propionic acid (C3), however, had positive effect to decrease $\mathrm{C} 2 / \mathrm{C} 3$ ratio in treatments $\mathrm{G}+\mathrm{B}, \mathrm{G}+\mathrm{C}$, and $\mathrm{G}+\mathrm{D}$. Increasing total VFA in concentrate with addition probiotic is supported by data IVDMD in treatments $\mathrm{G}+\mathrm{B}, \mathrm{G}+\mathrm{C}$, and $\mathrm{G}+\mathrm{D}$.

Methane production from cattle in the tropics averaged $10-11 \%$ of gross energy intake. It has been demonstrated that $\mathrm{CH}_{4}$ production was suppressed by addition of $S$. cerevisiae (Lila et al., 2004; Mwenya et al., 2004). Concentrate containing $\mathrm{LAB}$ and yeast probiotics $(\mathrm{G}+\mathrm{B}, \mathrm{G}+\mathrm{C}$, $\mathrm{G}+\mathrm{D})$ had lower $\mathrm{CH}_{4}$ concentration $(\mathrm{P}<0.01)$ ranged $11-15 \%$ than control feed $(\mathrm{G})$ (Table 1 ). Concentrate containing $L$. plantarum and $L$. acidophilus $(\mathrm{G}+\mathrm{D})$ had the greatest effect to suppress $\mathrm{CH}_{4}$ production. The decrease $\mathrm{CH}_{4}$ concentration observed in concentrate containing LAB may due to the utilization of metabolic hydrogen by propionibacteria to produce propionic acid.

\section{Nutrient Digestibility}

Table 3 shows in vitro DM, OM and NDF digestibility of grass silage and concentrate containing probiotic. The IVDMD in substrate consisted of grass silage and concentrate was higher $(\mathrm{P}<0.01)$ compared to control feed. Addition of LAB and yeast probiotic increased IVDMD by $19.4 \%$ and $5 \%$ and IVNDFD when compared to feed without prcentrated increased 
Table 3. In vitro Digestibility (\%) of Dry Matter, Organic Matter and Neutral Detergent Fiber of Feeds

\begin{tabular}{lccccccr}
\hline & \multicolumn{5}{c}{ Treatments } & \multirow{2}{*}{ SEM } & P \\
\cline { 2 - 5 } & $\mathrm{G}$ & $\mathrm{G}+\mathrm{A}$ & $\mathrm{G}+\mathrm{B}$ & $\mathrm{G}+\mathrm{C}$ & $\mathrm{G}+\mathrm{D}$ & & \\
\hline IVDMD & $48.7^{\mathrm{b}}$ & $57.4^{\mathrm{a}}$ & $61.5^{\mathrm{a}}$ & $62.0^{\mathrm{a}}$ & $60.1^{\mathrm{a}}$ & 1.09 & $<0.01$ \\
IVOMD & $52.7^{\mathrm{b}}$ & $62.4^{\mathrm{b}}$ & 66.0 & 61.5 & 64.1 & 2.56 & 0.06 \\
IVNDFD & $48.8^{\mathrm{b}}$ & $51.1^{\mathrm{b}}$ & $56.2^{\mathrm{a}}$ & $52.8^{\mathrm{b}}$ & $53.8^{\mathrm{ab}}$ & 0.98 & $<0.01$ \\
\hline
\end{tabular}

G: grass silage; A: concentrate without probiotic; B: concentrate containing L. plantarum and S. cerevisiae; C: concentrate containing L. acidophilus and S. cerevisiae; D: concentrate containing $L$. plantarum and $L$. acidophilus

Mean values with different superscript letters within the same row are significantly different $(\mathrm{P}<0.01)$

IVDMD and IVNDFD by $5.6 \%$ and $6.1 \%$, respectively. This result was comparable to study reported by Lila et al. (2004) that addition of $S$. cerevisiae increased in vitro DM degradability. In other study, Krisnan et al. (2009) concluded that addition of probiotic collected from buffalo rumen in catalytic supplement increased NDF digestibility in sheep. Chaucheyras et al. (1995) noted that $S$. cerevisiae had ability to provide growth factors, such as organic acids or vitamins, thereby stimulating ruminal populations of cellulolytic bacteria.

\section{CONCLUSION}

In the present study, concentrate containing $\mathrm{LAB}$ and yeast was effective in modifying ruminal fermentation patterns by increasing the proportion of propionic acid, total VFA concentration, DM and NDF digestibility. Concentrate containing $L$. plantarum and $L$. acidophilus was more effective to reduce $\mathrm{CH}_{4}$ production compared to other probiotic. Decreasing $\mathrm{CH}_{4}$ from ruminants may have positive impact for the environmental sustainability.

\section{ACKNOWLEDGMENT}

This study was funded by the Directorate General of Higher Education, Indonesian Ministry of Education and Culture (Contract No. 030/SP2H/PL/Dit.Litabmas/V/2013).

\section{REFERENCES}

AOAC (Association of Official Analytical
Chemists). 2005. Official Methods of Analysis. $17^{\text {th }}$ Ed. Washington: AOAC International.

Abdulrazak, S. A., T. Fujihara, J. K. Ondiek and E.R. Ørskov. 2000. Nutritive evaluation of some Acacia tree leaves from Kenya. Anim. Feed Sci. Technol. 85:89-98.

Chaucheyras, F. G. Fonty, G. Bertin, J. M. Salmon and P. Gouet. 1995. Effect of Saccharomyces cerevisiae (Levucell SC), a microbial additive for ruminants, on lactate metabolism in vitro. Can. J. Microbiol. 42:927-933.

Fuller, R. 1989. Probiotics in man and animals. J Appl. Bacteriol. 66:365-378.

Hariadi, Tj. B. and B. Santoso. 2010. Evaluation of tropical plants containing tannin on in vitro methanogenesis and fermentation parameters using rumen fluid. J. Sci. Food Agric. 90:456-461.

Hong, H. A., L. H. Duc and S. M. Cutting. 2005. The use of bacterial spore formers as probiotics. FEMS Microbiol. Rev. 29:813835.

Krisnan, R., B. Haryanto and K. G. Wiryawan. 2009. Pengaruh kombinasi penggunaan probiotik mikroba rumen dengan suplemen katalitik dalam pakan terhadap kecernaan dan karakteristik rumen domba. JITV. 14 (4):262-269.

Lila, Z. A., N. Mohammed, T. Yasui, Y. Kurokawa, S. Kanda and H. Itabashi. 2004. Effects of a twin strain of Saccharomyces cerevisiae live cells on mixed ruminal microorganism fermentation in vitro. J. Anim. Sci. 82:1847-1854.

McDonald, P., A. R. Hunderson and S. J. E. 
Heron. 1991. The Biochemistry of Silage. $2^{\text {nd }}$ ed. Cambrian Printers Lt. Aberystwyth.

Menke, K. H. and H. Steingass. 1988. Estimation of the energetic feed value obtained from chemical analysis and in vitro gas production using rumen fluid. Anim. Res. Develop. 28:7-55.

Minson, D. J. and R. Milford. 1966. The energy values and nutritive value indices of Digitaria decumbens, Shorghum almum and Phaseolus atropurpureus. Aust. J. Agric. Res. 17:411-423.

Mwenya, B., B. Santoso, C. Sar, Y. Gamo, T. Kobayashi, I. Arai and J. Takahashi. 2004. Effects of including a 1-4 galactooligosaccharides, lactic acid bacteria or yeast culture on methanogenesis, energy and nitrogen metabolism in sheep. Anim. Feed Sci. Technol. 115:313-326.

Newbold, C. J. 1995. Probiotics for ruminants. Ann. Zootech. 45: 329-335.

Russell, J.B., J.D. O'Connor, D.G. Fox, P.J. Van Soest and C.J. Sniffen. 1992. A net carbohydrate and protein system for evaluating cattle diets. I. Ruminal fermentation. J. Anim. Sci. 70:3551-3561.

Santoso, B. A. Maunatin, B. Tj. Hariadi and H. Abubakar. 2013a. Isolasi dan idenstifikasi bakteri asam laktat asal rumput raja (Pennisetum purpureophoides) sebagai kandidat probiotik pada ternak. JITV 18(2):131-137.

Santoso, B. E. W. Saragih and B. Tj. Hariadi. 2013b. Effect of water extract of plants containing tannin on in vitro methanogenesis and fermentation characteristics of the grass. J. Indon. Trop. Anim. Agric. 38(1):47-54.

Santoso, B., B. Tj. Hariadi, Alimuddin and D. Y. Seseray. 2012. Fermentation characteristic of rice crop residue-based silage treated by epiphytic and commercial LAB. Med. Pet. 35(1):60-66.

Seo, J. K., S. W. Kim, M. H. Kim, S. D. Upadhaya, D. K. Kam and J. K. Ha. 2010. Direct-fed microbials for ruminant animals. Asian-Aust. J. Anim. Sci. 23:1657-1667.

Tilley, J. M. and R. A. Terry. 1963. A two stage technique for the in vitro digestion of forage crops. J. Brit Grassl. Soc. 18:104-111.

Van Soest, P. J. 1994. Nutritional Ecology of The Ruminant. ( $2^{\text {nd }}$ ed.). Comstock Publishing Associates a Division of Cornell University Press, Ithaca, NY, USA and London, UK. p. 476.

Van Soest, P. J., J. B. Robertson and B. A. Lewis.1991. Methods for dietary fiber, neutral detergent fiber, and nonstarch polysaccharides in relation to animal nutrition. J. Dairy Sci. 74:3583-3597. 